\title{
Líneas de Beau secundarias a enfermedad aguda en una mujer anciana
}

\author{
José Mauricio Ocampo \\ Servicio de Hospitalización Geriátrica Programa "Siéntete como en casa", \\ Corporación Comfenalco-Universidad Libre, Cali, Colombia
}

Las líneas de Beau fueron descritas por primera vez en 1846 por Justin Honore Simon Beau. Beau observó que estas líneas se presentaban semanas después del padecimiento de enfermedades febriles agudas. También encontró que el crecimiento normal de las uñas y el cabello se afecta, y estos hallazgos se convierten en indicadores de exposición previa a un evento agudo (1).

Se presentan como depresiones transversales y adelgazamiento focal en el lecho ungular, por el enlentecimiento del crecimiento de la placa ungular dorsal sobre la placa ventral (2). Estas líneas progresan de manera distal con el crecimiento normal de la uña y pueden desaparecer en los bordes laterales de la placa ungular.

El crecimiento de la placa dorsal que se produce desde la matriz proximal de la uña, se puede afectar por diferentes enfermedades sistémicas agudas (3). Aunque se desconoce el mecanismo exacto para la génesis de las líneas de Beau, se considera que su presencia refleja un cese temporal de la actividad mitótica en la matriz proximal de la uña, por disminución del flujo sanguíneo y el metabolismo (4). Lo anterior puede estar ocasionado por enfermedades sistémicas y febriles agudas, falla renal, síndrome de Stevens-Johnson, desnutrición, pénfigo, agentes quimioterapéuticos contra el cáncer y exposición al frío extremo en pacientes con enfermedad de Raynaud (4-6).

Cuando se compromete la mayoría de las uñas, se asocia con enfermedades sistémicas agudas, enfermedades dermatológicas, infecciones y exposición a fármacos o agentes tóxicos $(5,6)$. Por el contrario, cuando se afecta una o algunas uñas, se sugieren como factores etiológicos el trauma

Correspondencia:

José Mauricio Ocampo, Carrera 72B N ${ }^{\circ} 13 \mathrm{~A}-56$, apartamento 501A, Conjunto Residencial Pontevedra, Cali, Colombia jmocampo2000@yahoo.com.ar

Recibido: 23/11/12; aceptado:23/05/13 local o el síndrome del túnel del carpo (4). El tratamiento es el manejo de la condición de base y, una vez resuelta, el aspecto de la uña se normaliza cuando completa su crecimiento (3).

\section{Presentación del caso}

Se presenta el caso de una mujer de 77 años con antecedentes de hipertensión arterial, diabetes mellitus y dislipidemia. Ingresó al servicio de urgencias por un cuadro clínico de cinco días de evolución consistente en disnea, fiebre, tos, expectoración y alteraciones en el estado de conciencia. Se le diagnosticó neumonía adquirida en la comunidad y se inició su manejo. Durante su hospitalización desarrolló falla respiratoria, que requirió asistencia respiratoria mecánica y traslado a la unidad de cuidados intensivos. Cuando mejoró su condición clínica, se trasladó a sala de hospitalización y luego se dio de alta. A los dos meses de su egreso, asistió a la consulta externa, donde al examen físico se observaron las líneas de Beau en las uñas de sus manos (figura 1).

La presencia de las líneas de Beau en esta paciente se encuentran asociadas con el padecimiento de la enfermedad sistémica aguda, neumonía adquirida en la comunidad, que requirió manejo en la unidad de cuidados intensivos. Como las uñas crecen aproximadamente $1 \mathrm{~mm}$ cada seis a diez días (5), la distancia entre la línea de Beau y el borde proximal de la placa ungular puede ayudar a determinar el tiempo cuando se produjo el evento agudo, que en este caso fue aproximadamente dos meses atrás.

Por consiguiente, es importante que durante la práctica clínica se haga un adecuado examen físico de las uñas, porque su evaluación puede ofrecer información sobre antecedentes de enfermedades sistémicas agudas.

\section{Consideraciones éticas}

Para la publicación de este trabajo científico se llevó a cabo la realización y firma del consentimiento informado de la paciente. 

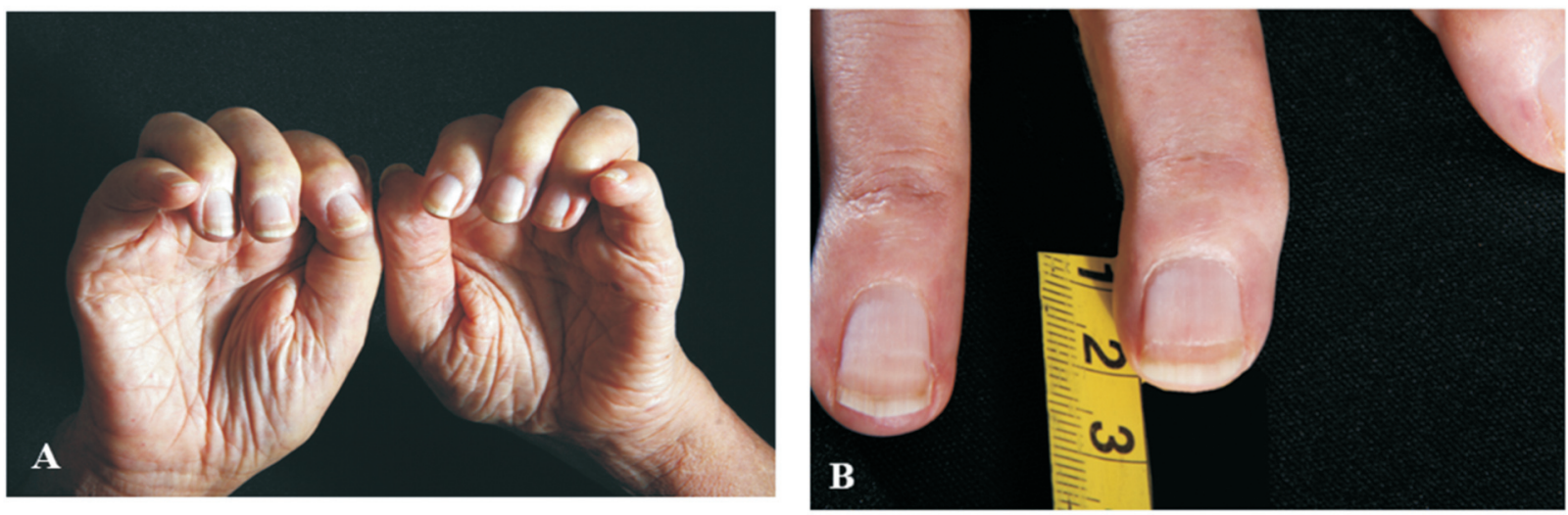

Figura 1. Líneas de Beau. A. Vista panorámica. B. Acercamiento.

\section{Conflicto de interés}

El autor del manuscrito declara no tener ningún conflicto de interés.

\section{Financiación}

El autor declara que para la elaboración de este trabajo científico no ha contado con ninguna fuente de financiación.

\section{Beau's lines secondary to acute illness in an elderly woman}

Beau's lines were first described in 1846 by Justin Honore Simon Beau, who observed they appeared weeks after the development of acute febrile diseases, becoming a retrospective indicator of them (1).

These lines look like transverse depressions and focal thinning at the nail bed level due to the slowing of the growth of the nail plate on the dorsal ventral plate (2). Then, they progress distally with the normal growth of the nail and may disappear at the side edges of the nail plate.

Dorsal plate growth from the proximal nail matrix can be affected by various acute systemic diseases (3). Although the exact mechanism for the genesis of Beau's lines is unknown, it is considered that their presence reflects a temporary cessation of mitotic activity at the proximal nail matrix level due to a decrease in blood flow and metabolism (4). This may be caused by systemic and acute febrile diseases, renal failure, Stevens-Johnson syndrome, malnutrition, pemphigus, chemotherapeutic agents for cancer, or exposure to extreme cold in Raynaud's disease patients (4-6).

When most of the nails are affected, it is associated with acute systemic diseases, dermatological diseases, infections, exposure to drugs or toxic agents $(5,6)$. Conversely, when one or a few nails are affected, the suggested etiological factors are local trauma or carpal tunnel syndrome (4). The treatment is to manage the base condition and with its resolution, the appearance of the nail returns to normal when it is finished growing (3).

\section{Case presentation}

A case of a 77-year-old woman with history of hypertension, diabetes mellitus and dyslipidemia is presented. She was admitted to the emergency room having a five-day history of dyspnea, fever, productive cough, and altered consciousness. She was diagnosed with community-acquired pneumonia and treatment was started. At the hospital, she developed respiratory failure, requiring mechanical ventilation and was transferred to the intensive care unit. When her clinical condition improved, she was moved to the general ward and was discharged. Two months later, during a physical examination at the outpatient clinic follow-up, Beau's lines were observed in her fingernails (Figures $1 \mathrm{~A}$ and $\mathrm{B}$ ).

The presence of Beau's lines in this patient is associated with the condition of severe acute illness requiring management in the intensive care unit. As the nails grow about one mm every six to ten days (5), the distance between the Beau line and the proximal edge of the nail plate can help to determine the time when the acute event occurred, which in this case was about two months prior.

Therefore, it is important for physicians to perform the physical exam of the nails during clinical practice, because a proper assessment can provide important clues for the diagnosis of several systemic diseases. 


\section{Ethical considerations}

For the publication of this scientific study, we had a signed informed consent from the patient.

\section{Referencias}

1. Beau JHS. Note sur certains carateres de semeiologie retrospective presentes par les ongles. Arch Gen Med. $1846 ; 11: 447$

2. Park J, Li K. Multiple Beau's lines. $\mathrm{N}$ Engl J Med. 2010;362:e63. http://dx.doi.org/10.1056/ NEJMicm0906698
3. Tully AS, Trayes KP, Studdiford JS. Evaluation of nail abnormalities. Am Fam Physician. 2012;85:779-87.

4. Lee YJ, Yun SK. Unilateral Beau's lines associated with a fingertip crushing injury. J Dermatol. 2005;32:914-6.

5. Gregoriou S, Argyriou G, Larios G, Rigopoulos D. Nail disorders and systemic disease: What the nails tell us. J Fam Pract. 2008;57:509-14.

6. Huang TC, Chao TY. Mees lines and Beau lines after chemotherapy. CMAJ. 2010;182:E149. http://dx.doi. org/10.1503/cmaj.090501 